\title{
Lemuru Fish Oil (Sardinella longiceps) Therapy on Periodontal Wistar Rats Induced with Porphyromonas gingivalis Bacteria: Osteoblast and Osteoclast
}

Wistar Sıçanlarında Porphyromonas gingivalis Bakteri ile Elde Edilen Periodontal hastalıkta Lemuru Balık Yağ

\author{
Dian W Damaiyanti ${ }^{1}$, Widyastuti Widyastuti ${ }^{2}$, Ayulistya Paramita ${ }^{3}$, \\ Aditya Megantara ${ }^{1}$, Mohammad Ibrohim ${ }^{1}$ \\ ${ }^{1}$ Oral Biology Department Faculty of Dentistry Universitas Hang Tuah Surabaya, Indonesia \\ ${ }^{2}$ Periodontia Department Faculty of Dentistry Universitas Hang Tuah Surabaya, Indonesia \\ ${ }^{3}$ Pedodontia Department Faculty of Dentistry Universitas Hang Tuah Surabaya, Indonesia
} ORCID

Dian Widya DAMAIYANTI: https://orcid.org/0000-8894-074X

\author{
Yazıșma Adresi / Correspondence: \\ Dian Widya DAMAIYANTI \\ Department of Oral Biology, Faculty of Dentistry Hang Tuah University, Jl Arif Rahman Hakim 150, Surabaya, Indonesia \\ T: 031-71536336 E-mail: damaiyanti@hangtuah.ac.id
}

Geliș Tarihi / Received : 29-07-2019 Kabul Tarihi / Accepted : 26-08-2019 Yayın Tarihi / Online Published: 29-08-2019

Damaiyanti D.W.,Widyastuti W., Paramita A.,Megantara A, Ibrohim M., Lemuru Fish Oil (Sardinella longiceps) Therapy on Periodontal Wistar Rats Induced with Porphyromonas gingivalis Bacteria: Osteoblast and Osteoclast, J Biotechnol and Strategic Health Res. 2019;3(2):128-134 DOİ:10.34084/bshr.597830

\footnotetext{
Abstract

Objective Periodontitis is an inflammatory disease of tooth-supporting tissue, caused by the bacterium such as Porphyromonas gingivalis. Inflammation that not treated can lead to resorption of alveolar bone. It is suggested that supportive medicines are needed to regenerate bone, one of them is lemuru fish oil gel (Sardinella Longiceps). Lemuru fish oil can act as an immunomodulator and anti-bacterium. Flavonoid content in fish oil plays a role to inhibit lipid peroxidation so it is effective in killing bacteria that can reduce LPS production. The content of eicosapentaenoic acid (EPA) and docosahexaenoic acid (DHA) in lemuru fish oil lead to modulate IL-10, inhibition the production of pro-inflammatory cytokines such as interleukin-1 beta (IL-1 $\beta$ ), prostaglandin-E2 (PGE2), tumor necrosis factor alfa (TNF $\alpha$ ) that will decrease receptor activator of nuclear factor kappa-B - ligand (RANK-RANKL) band and result is increased osteoblast, decreased osteoclasts number which speeds up the bone regeneration process Objective: To determine the effect of topically applying lemuru fish oil in on periodontal Wistar Rats after induction of Periodontitis with P.gingivalis bacteria.

Materials and Experimental research laboratories with post-test only control group design. Samples of 25 male Wistar rats divided into 5 groups. K- (no induction), K (induced with P.

Methods gingivalis), P1 (induced with P. gingivalis and 10\% lemuru oil gel therapy), P2 (induced with P. gingivalis and 20\% lemuru fish oil gel therapy), P3 (induced with P. gingivalis and $40 \%$ lemuru oil gel therapy). Induction of the bacterium P.gingivalis was carried out, then the lemuru fish oil gel was given to gingival sulcus for 14 days. Observations were made by calculating osteoblast and osteoclast cells in histology samples using HE (Hematoxylin Eosin).

Results The LSD statistic test showed a significant difference between the P. Gingivalis induction group with no treatment and treatment group using lemuru fish oil. The treatment using lemuru fish oil gel can increase the number of osteoblasts and decrease the number of osteoclast to the induction of P.gingivalis bacteria, with the most effective number of osteoblasts found in P2 group with a concentration of $20 \%$ lemuru fish oil gel therapy.

Conclusion Topical Lemuru Fish oil gel can be used as alveolar bone regeneration therapy on periodontitis induced with P.gingivalis.

Keywords Topical lemuru fish oil gel, Osteoblasts, Osteoclast, Periodontitis, Phorphyromonas gingivalis.
}

Özet

Amaç Periodontitis, Porphyromonas gingivalis gibi bakterilerin neden olduğu enflamatuar bir diși destekleyen dokular hastalğı̆dır. Tedavi edilmeyen iltihap alveoler kemiğin emilmesine neden olabilir. Kemiğ̈in yenilenmesi için desteklevici ilaçlara ihtivac duyulduğu önerilmektedir, bunlardan biri lemuru balık yağı jelidir (Sardinella Longiceps). Lemuru balık yağı, bir immünomodülatör ve anti-bakteriyel etki gösterebilir. Balık yağındaki flavonoid içeriği, lipit peroksidasyonunu inhibe etmede rol oynar, bu nedenle LPS üretimini azaltabilecek bakterilerin öldürülmesinde etkilidir. Lemuru balik yağındaki eikosapentaenoik asit (EPA) ve dokosahekssaenoik asitin (DHA) içeriğ̈i, interlökin-1 beta (IL-1 $\beta$ ), prostaglandin-E2 (IL-1 $\beta$ ), prostaglandin-E2 (IL-1 B) gibi pro-enflamatuar sitokinlerin üretimini inhibe eder. PGE2), nükleer faktör kappa-B - ligand (RANK-RANKL) bandinın reseptör aktivatörünü azaltacak olan tümör nekroz faktörü alfa (TNFa) ve sonuçta osteoblast artar, kemik rejenerasyon işlemini hzzlandıran osteoklast sayısını düşürür. Çalışmada topikal lemuru balık yağının, Wistarlarda P.gingivalis periodontiti tedavisine etkisinin belirlenmesi amaçlanmıştır.

Materyal ve Test ve kontrol grubu için deneysel arașttrma laboratuvarlarında 25 erkek Wistar ratı 5 gruba ayrıld. K- (indüksiyon yok), K (P.gingivalis ile indüklenmiş), P1 (P.gingivalis ve\% 10 lemuru yă̆

Metod jel terapisi ile indüklenmiş), P2 (P.gingivalis ve\% 20 lemuru balık yağı jel terapisi ile indüklenmiş), P3 (P.gingivalis ve\% 40 lemuru yağ jeli tedavisi ile indüklenmiștir). Bakterinin indüksiyonu P.gingivalis yapıldı ve daha sonra lemuru balı yağı jeli, 14 gün boyunca gingival sulkusa sürüldü. Hematoksilen Eosin(HE) boyası ile histoloji örneklerinde osteoblast ve osteoklast hücreleri hesaplanarak gözlemler yapild.

Bulgular LSD istatistik testi lemuru ballk yağı kullanılarak tedavi ve tedavi grubu olmayan P.gingivalis indüksiyon grubu arasında anlamlı bir fark gösterdi. Lemuru balık yağı jeli kullanılarak yapılan muamele, osteoblast sayısın artırabilir ve P2 grubunda\% 20 lemuru balk yağı jeli terapisi en etkili osteoblast sayısı vermiş ve osteoklast sayısını azaltabildiği gösterilmiștir.

Sonuç Topikal Lemuru Balık yağı jeli, P.gingivalis ile indüklenen periodontitlerde alveoler kemik rejenerasyon tedavisi olarak kullanılabilir 


\section{INTRODUCTION}

Periodontitis is an inflammatory disease of the tooth-supporting tissue, one of them is caused by bacteria that can cause damage to collagen fibers and alveolar bone, where the damage caused is progressive and results in periodontal ligament damage and alveolar bone loss accompanied by increased probing depth, recession, and both ${ }^{1.2}$ The prevalence of dental and oral diseases in Indonesia is based on riskesdas of $25 \%$. Periodontitis is the second most common disease after caries in Indonesia. prevalence for healthy periodontal tissue is $4.79 \%$ or 34614 people while unhealthy tissue is $95.21 \%$ or 687715 people. $^{3}$

Based on research conducted by Pratiwi (2008) showed that periodontal tissue damage caused by the bacteria $\mathrm{P}$. gingivalis can cause periodontitis. ${ }^{4}$ Periodontitis begins with the accumulation of plaque containing pathogenic bacteria and toxins. Dental plaque bacteria will produce products, such as fatty acids (for example butyric acid and propionic acid), peptides such as $\mathrm{N}$-formilmethionyl-leucyl- phenylalanine (FMLP) and lipopolysaccharide (LPS) which will diffuse into the gingival epithelial layer. ${ }^{5}$

Bacteria P.gingivalis can produce Lipopolysaccharide (LPS), so activated macrophages and helper 1 cells T synthesize pro-inflammatory cytokines. Proinflammatory mediators such as TNF-alpha, IL-1, IL-6, PGE2 and MMPs cause inflammation in the periodontal tissues, during the inflammatory process bone-forming cells, namely osteoblasts decrease in number and activity and increase osteoclast cells. PGE-2 induces osteoblasts to produce receptor-activated nuclear kappa-B ligand (RANKL) and reduce osteoprotegerin (OPG) production. In addition, PGE-2 enhances the bond between RANKL and receptor-activated nuclear kappa-B (RANK) in osteoclast precursors. The decrease in OPG which functions to bind RANKL to form osteoblasts causes RANKL to bind to RANK which causes osteoclast formation. this causes the number of osteoblasts to decrease and the number of osteoclasts to increase. ${ }^{6,7,8}$
Periodontitis treatment includes mechanical therapy that is supported by antibiotic and anti-inflammatory drugs. Mechanical therapy is carried out, namely scaling and root planning, aimed at removing hard and soft deposits that are attached to the surface and roots of the teeth used as a place for bacterial attachment and growth. Antibiotic drugs such as tetracycline have a disadvantage, namely the resistance of bacterial oral cavity because tetracycline is a broad-spectrum antibiotic drug. Based on the consideration of the treatment that underlies the researchers to carry out the treatment with the administration of lemuru fish oil gel (Sardinella Longiceps). ${ }^{9}$

Sardine oil (Sardinella lemuru) is the one of fish target of fishermen from Banyuwangi who fish in Bali strait. Lemuru fish oil is usually traded for animal feed, release in leather tanning, paint and ink at low prices. Lemuru fish oil (Sardinella Longiceps) contains various compounds that are beneficial to health including protein, fat with omega 3, flavonoids, vitamins, DHA, EPA, EFA, minerals that are efficacious to prevent bone resorption. Flavonoids are antibacterial by inhibiting bacterial wall synthesis. The content of EPA and DHA can activate anti-inflammatory cytokines, namely, IL-10 will deactivate monocytes and macrophages, and reduce the production of pro-inflammatory cytokines, so that the number and activation of osteoclasts is inhibited making the number and activation of osteoblast cells increase. ${ }^{10,11}$

Based on this, the researchers wanted to find out the effect of Sardinella longiceps fish oil on the amount of osteoblast cell and osteoclast cell in the periodontal tissue of Wistar rats induced by P.gingivalis.

\section{METHOD}

All experiments were approved by the Faculty of dentistry Animal Care Committee komite etik penelitian kesehatan gigi (KEPKG) and performed following the guidelines of the Faculty of Dentistry, Universitas Hangtuah Council on Animal Care with number certificate 143/KEPK/XII/2018. 
The rats were divided into five groups $\mathrm{K}$ (induction group P.gingivalis), K- (group without induction), P1 (P.gingivalis, + Gmil 10\%), P2 (P.gingivalis + Gmil 20\%), and P3 (P.gingivalis + Gmil 40\%).

The condition of periodontitis with modification of Garlet methods obtained by bacterial induction using P.gingivalis (P.g) ATCC (American Type Culture Cell) 33277 as much as $2 \mathrm{ml}$ from $1 \times 109 \mathrm{CFU} / \mathrm{ml}$ is given orally, topically along the gingival sulcus, and rectum. Frequency of induction P.g 3 times in 4 days. Periodontal tissue damage takes 4 weeks to count since the first bacterial given. ${ }^{12,13}$ Bone Height was measured to determined periodontitis condition The height of bone was measured by digital caliper from alveolar crest to base of mandubula in posterior region

Lemuru fish oil was obtained from home industry in Bayuwangi city where lemuru fish oil waste from canning plants was processed to clarified by screening. Lemuru fish oil gel is made by using lemuru fish oil which is added by PEG 400 as an emulator and surfactant gum as a thickener then mixed and stirred on a hotplate until homogeneous. Lemuru fish oil gel is given topically $1 \mathrm{ml} /$ day for 14 days in the lower jaw gingival sulcus of wistar rats and using a micro brush. Therapy is carried out for 14 days because it corresponded to the length of the angiogenesis process, induction of osteoblasts, and overcoming the process of operator error. ${ }^{12}$

The animals were sacrificed on day 14 after therapy and alveolar bone specimens were acquired. Then the specimen processing technique was continued by the paraffin method and stain with Hematoxylin Eosin (HE). Histometric using Olympus CX-22 and optilab program, magnificent at 400x. The slide was divided into 6 fields of view. Histological analysis was carried out by two observers from histology department and was not involved in research to maintain objectivity. The amount of osteoblast and osteoclast was analyzed by ANOVA.

\section{RESULT}

Periodontitis rats model with induction P.gingivalis bacteria for 4 days induction and 4 weeks incubation, found the bone height decrease we as follows:

\begin{tabular}{|l|l|}
\hline \multicolumn{2}{|l|}{ Table 1. Alveolar Bone Height } \\
\hline Group & Mean \pm Std. $(\mathrm{mm})$ \\
\hline K (Bacterial Induction) & $4.6840 \pm 0.25$ \\
\hline K- (No Induction) & $5.2260 \pm 0.22$ \\
\hline
\end{tabular}

Bone height decrease was one of the signs of bone damage which is characterized of periodontitis.

The results of the research data were analyzed described to obtain an overview of the distribution and summarization of the data to clarify the presentation of results. Then hypothesis test was done using analytic statistics with a significance value of $95 \%(\mathrm{p}<0.05)$.

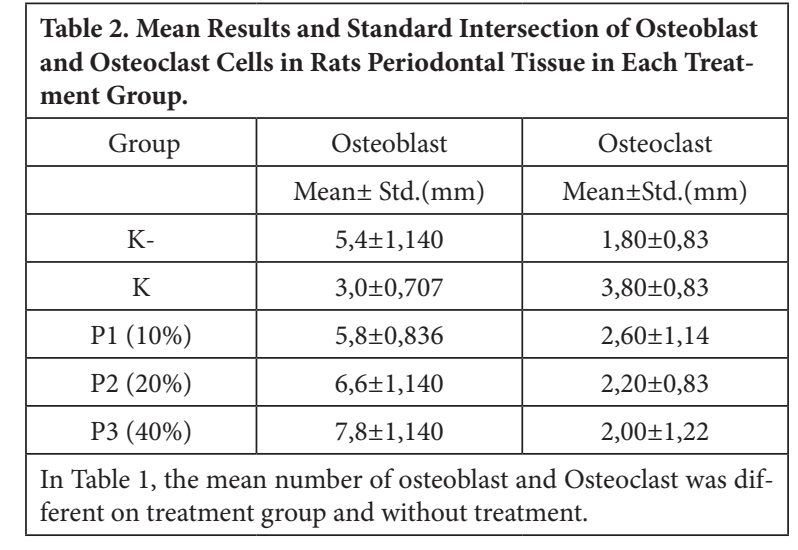

Table 2. Mean Results and Standard Intersection of Osteoblast ment Group. 


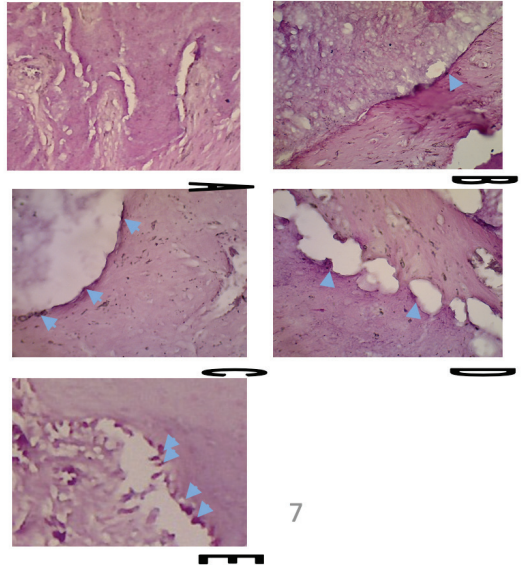

Figure 1. Picture of osteoblast anatomic histopathological preparation in 400x alveolar bone. A. Description of HE in group K-; B. Description of HE in group K; C. Description of $\mathrm{HE}$ in group P1; D. Description of $\mathrm{HE}$ in $\mathrm{P} 2$ group; E. Description of HE in group P3
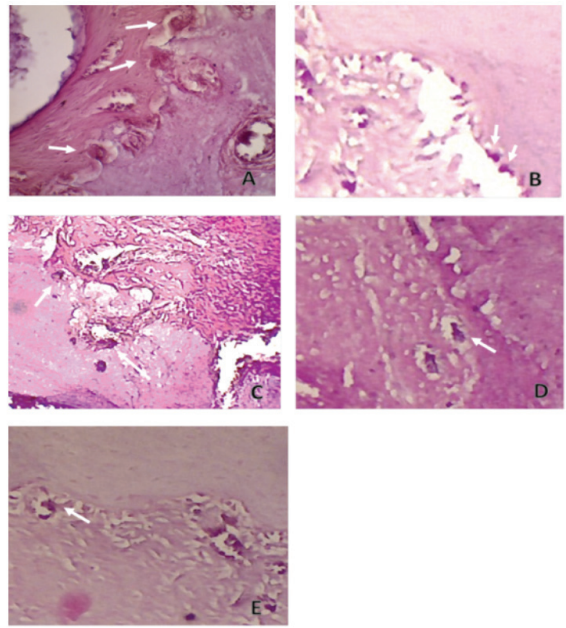

Figure 2. Pictures Osteoclast of histopathological preparations for 400X magnification A. Control group histopathological preparations for negative control group B. Control group histopathological preparations for negative control group C. Pictures of histopathological preparations for group P1 (10\% lemuru fish oil gel therapy). D. Histopathological preparations in P2 (20\% lemuru fish oil gel therapy) E. Images of histopathological preparations P3 (40\% lemuru fish gel therapy )

\section{Osteoblast Analysis}

The data which is normally distributed and homogeneous in variety were analyzed using parametric test, Post-hoc LSD, to know that there's a difference in the number of osteoblast in every treatment group of experimental animals. Based on the Post-hoc LSD test, it shows significant differences in every group which has a different treatment, when the significance $\mathrm{p}<0,05$.

\begin{tabular}{|l|c|c|c|c|}
\hline \multicolumn{6}{|l|}{ Table 3. Result of LSD test of Osteoblast cell } \\
\hline Group & $\begin{array}{c}\text { K- } \\
(\text { no PG) }\end{array}$ & $\begin{array}{c}\text { P1 } \\
(10 \%)\end{array}$ & $\begin{array}{c}\text { P2 } \\
(20 \%)\end{array}$ & $\begin{array}{c}\text { P3 } \\
(40 \%)\end{array}$ \\
\hline K (with PG) & $.001^{*}$ & .534 & .072 & $.001^{*}$ \\
\hline K- (no PG) & & $.000^{*}$ & $.000^{*}$ & $.000^{*}$ \\
\hline P1 (10\%) & & .220 & $.005^{*}$ \\
\hline P2 (20\%) & & .072 \\
\hline${ }^{*} \mathrm{P}<0,05$ (There is a difference)
\end{tabular}

Based on table 3, the results of the Post-hoc LSD test showed that there were significant differences in the number of osteoblast cells in rat periodontal tissue $(\mathrm{p}<0.05)$ in each group, namely in the group:

K - (- P.g) with K (+ P.g), K with P1 (+ P.g + L10\%), K with P2 (+ P.g + L20\%), K with P3 (+ P.g + L40\%).

Whereas there was no difference in the number of osteoblast cells in the periodontal tissues of rats in each group, namely in the $\mathrm{K}$ group with $\mathrm{P} 1, \mathrm{P} 2$, and P1 with $\mathrm{P} 2$, P2 and P3.

\section{Osteoclast Analysis}

Based on the one way anova test showed a significant difference between each group that had different treatments. Based on this, it is followed by the LSD test to find out which groups have differences, if the significance value was $<0,005$. 
Journal of BSHR 2019;3(2):128-134

DAMAIYANTI, WIDYASTUTI, PARAMITA, MEGANTARA, IBROHIM, Lemuru Fish Oil Therapy in Periodontitis

\begin{tabular}{|l|c|c|c|c|}
\hline Table 4. Result of LSD test of Osteoclast cell \\
\hline Group & $\begin{array}{c}\text { K- } \\
\text { (no PG) }\end{array}$ & $\begin{array}{c}\text { P1 } \\
(10 \%)\end{array}$ & $\begin{array}{c}\text { P2 } \\
(20 \%)\end{array}$ & $\begin{array}{c}\text { P3 } \\
(40 \%)\end{array}$ \\
\hline K (with PG) & $0.005^{*}$ & 0.070 & $0.019^{*}$ & $0.009^{*}$ \\
\hline K- (no PG) & & 0.216 & 0.530 & 0.753 \\
\hline P1 (10\%) & & 0.530 & 0.349 \\
\hline P2 (20\%) & & 0.753 \\
\hline${ }^{*}$ P $<0,05$ (There is a difference) \\
\hline
\end{tabular}

Based on table 4, the results of the LSD test showed that there were significant differences in the number of osteoclast cells $(\mathrm{p}<0.05)$ in each group, namely in the group: $\mathrm{K}(+\mathrm{PG})$ with K- (without PG), K (+ PG) with P2 (gmil 20\%) and K (+ PG) with P3 (gmil 40\%).

While there were no differences in the number of osteoclasts in each category, in category of $\mathrm{K}(+\mathrm{PG})$ with P1 (gmil 10\%), K- (without PG) with P1 (gmil 10\%), K (gmil $20 \%$ ) with P2 (gmil 20\%), K- (without PG) with P3 (gmil 40\%), P1 (gmil 10\%) with P2 (gmil 20\%), P1 (gmil 20\%) with P3 (gmil 10\%) with P3 (gmil 40\%) and P2 (gmil 20\%) with P3 (gmil 40\%). Clinically found differences between the control group and the treatment group. In the lemuru fish oil group, redness was not found in the gingiva and pockets that did not develop. This is proven by the results of studies that show differences in the number of osteoblast cells and osteoclast cells in the study

\section{DISCUSSION}

This study aims to prove the effectiveness of supportive therapy from lemuru fish oil (Sardinella longiceps) gel with concentrations of $10 \%, 20 \%$, and $40 \%$ with indicators of the number of osteoblast and the reduction of osteoclasts in periodontal tissue of wistar rats after induction of P. gingivalis bacteria.

EPA and DHA act as immunomodulators by inhibiting the production of proinflammatory cytokines namely IL-1, IL6, and TNF- $\alpha$. EPA and DHA will regulate inflammation through increased production of RANKL and OPG. Inc- reased production of OPG will inhibit the bond between RANK and RANKL, causing increased osteoblasts. EPA has been shown to help fibroblasts to synthesize collagen. By increasing the amount of collagen osteoclasts are suppressed and the number of osteoblasts increases. ${ }^{13,14,15}$

Hypothesis test results obtained a significant value of .000 which means there is a significant difference between the treatment group and the control group. the results of this study found that lemuru fish oil can increase the number of osteoblast cells on the 14th day after induction of P.gingivalis bacteria so that the inflammatory process and bone resorption are inhibited. Giving the lemuru fish oil gel in the gingival sulcus is expected to inhibit the inflammatory process and bone resorption reduces the osteoclast cell due to the induction of P.gingivalis.

The results of this study can be seen osteoblasts in the normal group (K-) had more numbers than the group induced by P.gingivalis. Meanwhile the normal group without induction in this study had a lower and significant number of osteoclasts compared to the PG induction group and this showed that the induction of P.gingivalis produced toxic compounds such as LPS which could trigger increased cell production such as macrophages and fibroblasts to produce inflammatory mediators such as IL 1 , TNF $\alpha$ \& PGE 2 which stimulates preosteoclasts and maturation of osteoclasts, resulting in bone resorption. ${ }^{1}$

The group with P.gingivalis induction and 10\% lemuru fish oil gel therapy (P1) in this study had a higher number of osteoblast cells than the normal group (K-), this showed an increase in osteoblast cell production, but was not significant according to the LSD test. Another result group with P.gingivalis and 10\% lemuru fish oil gel therapy (P1) had a higher number of osteoblast cells than the group with P.gingivalis induction and without lemuru fish oil gel therapy $(\mathrm{K})$. This proof that the induction of P.gingivalis significantly reduces the number of osteoblast cells. Bacterial induction with therapy $20 \%$ and $40 \%$ lemuru fish oil 
Journal of BSHR 2019;3(2):128-134

DAMAIYANTI, WIDYASTUTI, PARAMITA, MEGANTARA, IBROHIM, Lemuru Fish Oil Therapy in Periodontitis

therapy showed the higher result on number of osteoblast cell and lower number of osteoclast cell than in group with $10 \%$ lemuru fish oil therapy (P1).

Lemuru fish oil gel therapy contains EPA and DHA that can inhibit osteoblast cell apoptosis, so the number of osteoblast cells will increase and the number of osteoclast cells will decrease. Group of P.gingivalis bacterial induction with $20 \%$ lemuru fish oil therapy (P2) is effective and increases in the number of osteoblasts and reduces the number of osteoclasts because DHA and EPA in lemuru fish will inhibit proinflammatory cytokine production then decrease proosteclast stimulation.

The group with induction of P.gingivalis and 40\% lemuru fish oil gel therapy (P3) has the highest average number of osteoblast cells and lowest number of osteoclast cell but not significant difference compare to group with induction of P.gingivalis and 200\% lemuru fish oil gel therapy (P2). This shows the $20 \%$ lemuru fish oil gel also gave the same effect as $40 \%$ lemuru fish oil gel.

Research group with induction of P.gingivalis and lemuru fish oil gel therapy proof the effect of lemuru fish oil gel can improve the number osteoblast cells and decrease the number of osteoclast cell through IL-10 secretion produced by $\mathrm{T}$ cell helper 2 which is able to inhibit synthesis of proinflammatory cytokines produced by $\mathrm{T}$ cell helper 1 by macrophages. The decrease of cytokines proinflammatory IL-1, IL- 6 as well as TNF- $\alpha$ is closely related to the decrease in osteoclast number, and the increase number of osteoblasts. Cytokines proinflammatory can be directly reduced osteoblast apoptosis and the precursor. ${ }^{7}$

Eicosapentaenoic acid (EPA) and docosahexaenoic acid (DHA), respectively. N-3 PUFAs consumption is linked to the development of the brain and nervous tissue in infants and visual function and reduces the incidence of coronary heart disease. ${ }^{22}$ Based on Sri Wahjuni research proofed that sardinella longiceps oil in Wistar rat acts as anti dislipide- mia by increasing the HDL-C levels. ${ }^{23}$ Research conducted by Indahyani (2013), lemuru fish oil reduced the osteoblast apoptosis of rats alveolar bone induced periodontal infection by LPS. ${ }^{8}$

Based on this study, lemuru fish oil gel (Sardinella longiceps) can be used to increase the number of osteoblast cells and decrease the number of osteoclast cell after the induction of P.gingivalis as periodontitis model, and optimum in concentration $20 \%$. Lemuru fish oil gel in this study still has a strong odor so that further research needs to be done on Lemuru fish oil gel preparations to complete organoleptic requirements

\section{CONCLUSION}

Giving lemuru fish oil gel can increase the number of osteoblasts and decrease the number osteoclast cell to the induction of P.gingivalis, with the most effective is on the concentration of $20 \%$ lemuru fish oil gel. 
Journal of BSHR 2019;3(2):128-134

DAMAIYANTI, WIDYASTUTI, PARAMITA, MEGANTARA, IBROHIM, Lemuru Fish Oil Therapy in Periodontitis

\section{Kaynaklar}

1. Newman, M.G., Carranza, F.A., Bulkacz, J. Quireynen, M., Teughels, W., \& Haake, S.K. Microbiology Of Periodontal Disease In Carranza's Clinical Periodontology (10th Ed.). Philadelphia: W.B Sunders; 2006: 171-172.

2. Sudirman, P. L., Tirtayasa, K., \& Adiatmika, I. P. G. Skeling Dan Terpinen-4-Ol Type 1\% Menurunkan Kadarkolagenase Lebih Banyak Daripada Skeling Dan Chlorhexidine Digluconate 0, 12\% Pada Periodontitis Kronis Akibat Kalkulus. MEDICINA, 2017; 48(1): 68-70.

3. Mawaddah, N., Arbianti, K. \& Niluh Ringga W. Perbedaan Indeks Kebutuhan Perawatan Periodontal (Cpitn) Anak Normal Dan Anak Tunarungu. Odonto Dental Journal, 2017; 4(1): 44-49.

4. Praptiwi., Inokulasi Bakteri Dan Pemasangan Cincin Ligatur Untuk Induksi Periodontitis Pada Tikus. Majalah Kedokteran Gigi, 2008; 15(1): 81-84.

5. Yustina Ade Ratri., Ketut Suardita., Dian Agustin W. Peningkatan Jumlah Osteoklas pada Keradangan Periapikal Akibat Induksi Lipopolisakarida Porphyromonas Gingivalis (Suatu Penelitian Laboratories menggunakan Tikus). JBP, 2012; 14(3): 140-144.

6. Rofii, M., Satoto, H., \& Harahap, M. S. Perbandingan Kadar IL-10 Serum dengan dan Tanpa Infiltrasi Levobupivakain pada Nyeri Pasca Insisi. Jurnal Anestesiologi Indonesia, 2010; 2(2):34-37.

7. Kristanti, R. A. Penggunaan Doksisiklin Hyclate Sebagai Inhibitor Matriks Metalloproteinase Pada Terapi Tambahan Periodontitis. Sainstis, 2012; 1(2): 67-71.

8. Indahyani, D. E. Minyak Ikan Lemuru (Sardinella Longicep) Menurunkan Apoptosis Osteoblas Pada Tulang Alveolaris Tikus Wistar (Fish Oil Of Lemuru (Sardinella Longicep) Reduced The Osteoblast Apoptosis In Wistar Rat Alveolar Bone). Dental Journal: Majalah Kedokteran Gigi, 2013; 46(4): 185-189.

9. Hanafi, P., \& Sulistyorini, R. Perbandingan Pengaruh Ekstrak Pisang-Pisanga (Heliconiarostrata) Dengan Tetrasiklin Terhadap Bakteri Penyebab Periodontitis. In Prosiding Seminar Nasional \& Internasional, 2016; 1(1): 434-435.

10. Krismariono, A. Antibiotika Sistemik Dalam Perawatan Penyakit Periodontal. Periodontal Journal, 2009; 1(1): 7-15.

11. Lumbessy, M., Abidjulu, J., \& Paendong, J. J. Uji Total Flavonoid Pada Beberapa Tanaman Obat Tradisonal Di Desa Waitina Kecamatan Mangoli Timur Kabupaten Kepulauan Sula Provinsi Maluku Utara. Jurnal Mipa Unsrat Online, 2013; 2(1): 50-55.

12. Abdulloh, A. Pengaruh Kurkumin Dan Omega-3 Terhadap Survival Mencit Balb/C Model Sepsis Cecal Inoculum (Doctoral Dissertation, Universitas Sebelas Maret), 2010: 16-17.
13. Garlet, G. P., Avila-Campos, M. J., Milanezi, C. M., Ferreira, B. R., \& Silva, J. S. Actinobacillusactinomycetemcomitans-induced periodontal disease in mice: patterns of cytokine, chemokine, and chemokine receptor expression and leukocyte migration. Microbes and infection, 2005; 7(4): 738-747.

14. Collins, C. T., Makrides, M., Gibson, R. A., McPhee, A. J., Davis, P. G., Doyle, L. W., \& Ryan, P. Pre-and post-term growth in pre-term infants supplemented with higher-dose DHA: a randomised controlled trial. British journal of nutrition, 2011; 105(11): 1635-1643.

15. Cakırca, G., Mete, N., Batmaz, I., Sariyıldız, M. A., Ulu, M. A., Yazmalar, L., \& Çevik, R. The relationship between bone mineral density and levels of RANKL, osteoprotegerin and cathepsin-K in patients with rheumatoid arthritis. Dicle Medical Journal/Dicle Tip Dergisi, 2012; 39(4): 83-89.

16. Rizky, W. Analisis Faktor yang Berhubungan dengan Kejadian Phlebitis pada Pasien yang Terpasang Kateter Intravena di Ruang Bedah Rumah Sakit Ar. Bunda Prabumulih. Jurnal Ners dan Kebidanan Indonesia, 2016; 4(2): 102-108.

17. Dhotre, P. S., Suryakar, A. N., \& Bhogade, R. B. Oxidative stress in periodontitis: A critical link to cardiovascular disease. Biomedical Research, 2011; 22(2): 15-17.

18. Puspitaningrum, d. K. Pengaruh pemberian minyak ikan lemuru (sardinella longiseps) dan vitamin c terhadap jumlah osteoklas pada tikus wistar yang mengalami periodontitis 2012:31-32.

19. Susanto, E., \& Fahmi, A. S. Senyawa Fungsional Dari Ikan: Aplikasinya Dalam Pangan. Jurnal Aplikasi Teknologi Pangan, 2012; 1(4): 95-97.

20. Kurniawan, A., Budimawan, and Darma, $R$. The direction of Development of Fish Processing and Marketing Center in Kecamatan Lekok Pasuruan Regency. Thesis; 2013: 24-27.

21. Heim, K. E., Tagliaferro A. R., \& Bobilya., D. J. Flavonoid Antioxidants: Chemistry, Metabolism and Structure-Activity Relationships. J. Nutr. Biochem, 2002; 1(3): 572-584.

22. Khoddami A, Ariffin AA, Bakar J, Ghazali HM. Fatty acid profile of the oil extracted from fish waste (head, intestine and liver)(Sardinella lemuru). World Applied Sciences Journal. 2009; 7(1):127-31.

23. Wahjuni S. Pemberian Minyak Ikan Lemuru (Sardinella longiceps) sebagai Anti Dislipidemia Melalui Peningkatan HDL pada Tikus Wistar. Jurnal Kimia (Journal of Chemistry). 2011;5(2): 156-162 